\title{
BUSINESS
}

\section{Regulator under siege}

\section{Science at the Food and Drug Administration is in need of a revamp, as Meredith Wadman reports.}

\section{T}

he US Food and Drug Administration (FDA) has had a tough year. The Maryland-based agency, whose 10,000 staff are responsible for overseeing most aspects of food and drug safety, used to enjoy an enviable reputation as one of the world's most trusted regulators - especially in the field of drug safety, where many other nations simply follow its lead.

But in March, the agency's difficulties in ensuring food safety came under scrutiny after thousands of dogs and cats became ill and at least 16 died from eating pet food laced with melamine, an ingredient used in plastics. The chemical was traced to a Chinese-made ingredient in the pet food. And late last month, a high-powered panel of academics and industry managers delivered a stinging rebuke on the agency's scientific capability.

"The impact of the deficiency is profound precisely because science is at the heart of everything FDA does," says the report. "The agency will flounder and ultimately fail without a strong scientific foundation."

FDA: Science and Mission at Risk was written by a panel chaired by Gail Cassell, vice-president of research at drugmaker Eli Lilly, and delivered to the agency's scientific advisory board on 3 December. Agency commissioner Andrew von Eschenbach had asked for the assessment a year ago.

\section{Fallback}

The report claims that "American lives are at risk" because of what it terms "scientific deficiencies". It adds: "Not only can the agency not lead, it cannot even keep up with the advances in science," and calls for a doubling of congressional funding for the agency within two years.

The document is the latest in a long line of such diagnoses: last year, for example, the Institute of Medicine offered a stark assessment of the FDA's drug-safety capabilities (see Nature 443, 372; 2006).

"If the agency had no new

responsibilities, it would be inadequately funded," says William Hubbard, a former associate commissioner at the FDA. "When you add the fact that Congress is piling on new responsibilities and new workloads in things such as food imports, it makes the situation particularly dire."

Scott Gottlieb was the agency's deputy commissioner for policy until earlier this year and is now a fellow at the conservative American Enterprise Institute in Washington DC. He says that "the agency has probably reached a tipping point, partly because of the systemic lack of funding that has gone on for a very long time - but even more so because the complexity of its work and the risks inherent in the products it oversees have grown so much in the past few decades."

Funding for the agency has stagnated even

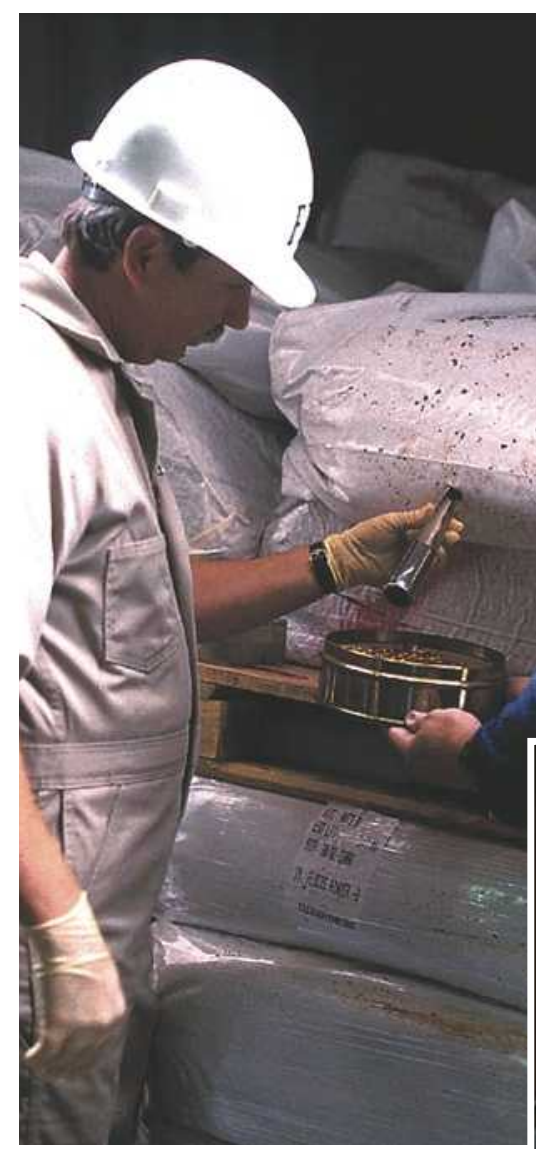

Former FDA official William Hubbard (right) doesn't think the agency has the resources to adequately police food imports. though Congress has enacted 123 statutes over the past 20 years that add to its regulatory responsibilities. Almost all the statutes require scientific expertise, yet none has come with extra public money, and the number of FDA employees that congressional funds support is roughly the same as it was 15 years ago.

Drug industry 'user fees' have, however, substantially augmented the agency's income since they were introduced in 1993, taking pressure off Congress. In 2008, the fees are expected to exceed $\$ 460$ million, but they are mostly targeted at drug and device review, and other functions have suffered since they were introduced. The operating budget of the FDA's Center for Food Safety and Applied Nutrition, for example, is a little over half of what it was in 2003.

\section{Dire diagnosis}

But the Pharmaceutical Research and Manufacturers of America (PhRMA), the drug industry's main lobby group, called the report "too grim". The report's "dire warnings about the scientific expertise of the FDA and its ability to do its demanding regulatory job would appear to be more than a little premature", says Alan Goldhammer, the group's deputy vicepresident for regulatory affairs. Goldhammer notes that next year, user fees will augment the congressional budget of $\$ 1.6$ billion by nearly $30 \%$.

Some commentators who are wary of calls for government spending, such as Gottlieb, support the report's conclusions. Yet most observers fear that it is unlikely to have much immediate effect on a financially constrained Congress. And with the signing of a new, fiveyear user-fee law in September, that train for new FDA money has already left the station. "Congress has a long history of ignoring these kinds of reports," says Gottlieb, "especially when they assign some of the blame to Congress - which this report does."

On the ground at the FDA, the publication will probably do nothing to quell recruitment and retention probto dog the agency. For some employees, it is already too late. "I felt that I could accomplish more with my skills and experience out in industry," says a former device reviewer, who added almost one-third to his salary when he left the FDA last year, "and that industry would appreciate me more." \section{$\frac{1}{2}$}

